\title{
THE RELATIONSHIP BETWEEN BOARD CHARACTERISTICS AND CORPORATE DIVIDEND POLICY: EVIDENCE FROM JORDAN
}

\section{YÖNETIM KURULU ÖZELLIKLERİ İLE KURUMSAL TEMETTÜ POLITTIKASI ARASINDAKİ İLIŞKİ: ÜRDÜN ÜZERINE BİR ARAŞTIRMA}

\author{
Ari Muhammad Rashid Amedi ${ }^{a}$, Aree Saeed Mustafa ${ }^{b *}$ \\ a, Dr., University of Duhok, Faculty of Business and Economic, ariamedi@ live.com, ORCID:0000-0001-8112-6614 \\ $b^{*}$ Corresponded Author,Dr., University of Duhok, Faculty of Business and Economic, areealamedi@gmail.com, ORCID: \\ 0000-0002-4889-1100
}

\section{ARTICLE INFO \\ Article history: \\ Received 18.08.2020 \\ Revised 23.10.2020 \\ Accepted 10.12.2020}

Keywords: Corporate dividend policy, board characteristics, Amman Stock Exchange

Jel Codes: G35, L22

\section{ARAŞTIRMA MAKALESİ \\ BENZERLIK/ PLAGIARISM}

Ithenticate : \%14

\section{MAKALE BİLGÍLERİ}

Makale Tarihçesi:

Gönderilme Tarihi 18.08.2020

Düzenleme 23.10.2020

Kabul Tarihi 10.12 .2020

Anahtar Kelimeler Kurumsal temettü politikasl, yönetim kurulu özellikleri, Amman Borsası

Jel Kodlar1: G35, L22

\begin{abstract}
This paper examines the impact of Board characteristics (board size, board independence, and board gender) on the corporate policy of dividend for a set of 132 firm-year listed companies of the manufacturing sector from Amman Stock Exchange between the years 2016-2018.. The paper uses logistic regression in analyzing the sample and the results show that there is a positive relationship between the Board of directors' characteristics (Board size, board diversity depicted as outside directors and board gender) and the corporate dividend policy. Our recommendations are that Jordanian manufacturing companies should comply with the Jordanian code of corporate governance and diversify their corporate boards of directors by appointing more outside directors and more female directors within their boards. This will also help to create a healthy relationship between the boards and the owners of the firms or the shareholders and minimize the agency conflict theory
\end{abstract}

\section{ÖZET}

Bu makale, 2016-2018 yılları arasında Amman Menkul Kıymetler Borsası'ndan imalat sektörünün borsada işlem gören 132 şirketten oluşan bir dizi şirket için Yönetim Kurulu özelliklerinin (yönetim kurulu büyüklüğü, yönetim kurulu bağımsızlığl ve yönetim kurulu cinsiyeti) kurumsal temettü politikası üzerindeki etkisini incelemektedir. Örneklemin analizinde lojistik regresyon kullanılmıştır ve sonuçlar, yönetim kurulunun özellikleri (Kurul büyüklüğ̈̈, yönetim kurulu dişı yöneticiler ve yönetim kurulu cinsiyeti olarak gösterilen yönetim kurulu çeşitliliği) ile kurumsal temettü politikası arasında pozitif bir ilişki olduğunu göstermektedir. Önerilerimiz, Ürdünlü imalat şirketlerinin Ürdün kurumsal yönetişim kurallarına uymaları ve yönetim kurullarına daha fazla dış direktör ve daha fazla kadın direktör atayarak kurumsal yönetim kurullarını çeşitlendirmeleri yönündedir. Bu aynı zamanda yönetim kurulları ile firmaların sahipleri veya hissedarlar arasında sağlıklı bir ilişki oluşturmaya ve kurum çatışma teorisini en aza indirmeye yardımci olacaktır.

\footnotetext{
APA STYLE RESOURCE USAGE: Amedi, A , Mustafa, A . (2021). THE RELATIONSHIP BETWEEN BOARD CHARACTERISTICS AND CORPORATE DIVIDEND POLICY: EVIDENCE FROM JORDAN . Muhasebe ve Finans Incelemeleri Dergisi , 4(1), 1 - 9 . DOI: 10.32951/mufider.782388
} 


\section{INTRODUCTION}

The highest organ of any firm is its board of directors. The members of the board have the authority to make changes to the firm's executive managements in addressing the agency theory (Fama $\&$ Jensen, 1983). For instants when managers make an important decision, it has to be signed and approved by the board before it can be executed.

Paying the dividends reduces the agency problem since it restricts the managers trying to invest extra cash flows available, for the sake of their personal interests, and bring no big benefit to the shareholders (Jensen, 1986). Moreover, when the firms tend to generate money by issuing new capital, the capital market will put the managers into more inspection when paying dividends (Easterbrook, 1984). La Porta, Shleifer, \& Vishny (2000) made a link between the dividends and corporate governance. They stated that board attributes of (size, composition, diversity and the tendency to dispense dividends) reduces the agency problem. Thus, the tendency to pay dividends and board attributes complete one another. One way of reducing the level of agency problem inside the firm is to have a powerful board of directors and to pay dividends (Fernández \& Arrondo, 2005). Because of that, it is believed that the higher of the board size, composition and diversity, the bigger the dividends are and the opposite is true. Yet, there is no clear evidence of a link between the tendency of paying dividends and each of the board size, composition and diversity. Majority of past studies did researches on the impact of board of directors' characteristics and the scale of paying dividends (Abor \& Fiador, 2013; Benjamin \& Zain, 2015). Yet a decision on the scale of paying dividends is considered after the agreement from the board directors. Therefore, a decision on paying the dividends must be present prior to the determination on the scale of dividends. A few number of researches have examined a relationship between the tendency to dispense dividends to the board size (Fernández \& Arrondo, 2005; Litai et al., 2011), the board composition (Hu \& Kumar, 2004; Litai et al., 2011; Sharma, 2011) and the board diversity (Byoun et al., 2016; Pucheta-Martínez \& Bel-Oms, 2016). There is a lack in the past researches since they concentrate on one or two variables in their studies and neither of them investigated the combined variables at once. Thus, this article is providing more testimony to the literature regarding a tendency to dispense dividends through an answer to the question of: Is bigger board size, board composition and more diversity will cause in bigger chance of paying dividends with the opposite?
The cross sectional and time series data have been used in this paper for a sample of companies taken by the Jordanian listed firms between 2016 to 2018. (Fama \& French, 2001; Fatemi \& Bildik, 2012; Kim \& Kim, 2013) and other scholars' attention are inclined to setting the primary characteristics of companies. They found out that the size of the company, ability of making new investments or growing and better earnings are significant factors influencing the decision to dispense dividends. (Jaara et al., 2018) shows that firm size has positive impact on dividend payments in Jordan.

Meanwhile, the corporate governance can serve as a monitor to safeguard the shareholders' interest in the firm (La Porta et al., 2000), as well as an effective exercise of the governance will result in a better chance of the paying dividends. Therefore, managers will have no chance to keep the cash and dispense it to the shareholders as dividends (Jiraporn et al., 2011; Short et al., 2002).

The Jordanian Corporate governance Code is a system, which was developed by 'The Department of Supervising Firms which belongs to the Jordanian Industries and Trading Ministry' in early 2003, that directs and control organizations. The corporate governance body decides on the allocation of the privileges and duties between various participants inside each organism - including the board members, managers, shareholders and other stakeholders - and set the rules and procedures to facilitate the process of making decisions. According to this Code, all firms must possess best size of Board of Directors and needed qualifications to reach its intended duties and commitments and be able to decide freely for the sake of the company taking into account stable combination of age, sex, and expertise.

Abbadi, Hijazi, and Al-Rahahleh (2016) documented a favorable effect between the fineness of corporate governance, the variety of the gender representatives of the board, and the dividend policy. They also found that female representatives are low in the Jordanian non-financial firms compared to other countries.

This paper consists of the introduction, literature review and hypothesis development. Then followed by methodology and definition of the variables, and finally the conclusion and summary. 


\section{RESEARCH DESIGN}

\subsection{Dependent Variable: Dividend Policy}

Dividend policy is firm's policy about paying the dividend from the earnings instead of keeping them as retained earnings in the firm. Dividend policy has an important role in both the firm's financing strategies and mitigating the agency problem (Okafor $\&$ Chijoke-Mgbame, 2011).

\subsection{Independent Variable: Board Size}

Board size referred to all of the board members sitting inside board for any firm. It consists of the independent, executive and non-executive directors. There are different views regarding the board size according to the evidences. One group of scholars see that the board size must be small assuming it that will impose better supervising role in the company and will have small likelihood of free riding problems (Jensen, 1993; Yermack, 1996). This symposium comes from the viewpoint of the agency theory.

Another (Certo, 2003; Dalton et al., 1999; De Villiers et al., 2011) see's the opposite of the above position and claim that larger board of directors will embrace diverse directors rich in resources. These directors will be a link to the outside environment. Whereas the final group argues that the board size and the operations must be aligned (Boone et al., 2007; Linck et al., 2008). Example to it is that small firms, expected to have a smaller board of directors and the opposite is true. Regardless of all that, there should be directors of boards in each firm to address the conflict between managers and owners.

Experimental evidence have revealed that there is a favorable link between probability of dispensing dividends and the size of the board. (Chen et al. 2011) discovered that a tendency of paying dividends and the size of the board is favorably correlated. It reveals that when firms have larger boards, the shareholders will have a higher return from their investments as dividends. (Al-Najjar \& Kilincarslan, 2016) also discovered a significant favorable relation amidst the probability of paying dividends and the size of the board using 264 firms listed in Stock Market of Istanbul. Each one of (Belden et al., 2005; Bokpin, 2011; Uwalomwa et al., 2015) also discovered the same evidence when testing the level of dividends payout, which is in accordance with the conclusion pattern of the dispensing the dividends poses as a control over propensity of management consuming available cash flows. Furthermore, according to the agency theory a small size of board of directors enables an effective and efficient supervising (Jensen, 1993). Moreover, (Jensen, 1993) extracted that vulnerable firms to the agency theory issue will anticipate to show higher tendency of dispensing dividends and the vice versa. Thus, our study hypothesizes that:

\section{H1: There is a positive link between a decision to dispense dividends and size of the board.}

\subsection{Independent Variable: Board Independence}

The non-executive directors' or 'independent' portion sitting within the board of directors is considered the board composition (Adjaoud \& BenAmar, 2010). Theories suggest that non-executive directors' or 'independent' original role is the observation of the management to insure the alignment of the interests of the agents and the principals (Jensen \& Meckling, 1979). More of that, it's proven that non-executive directors have a leading part in counseling as well as connecting firms with the external environment (Pfeffer \& Salancik, 2003). They can be the pundits, providing independent viewpoints to the board, add more variety with the expertise and experience they possess, which will result in a much better rendering (Latif et al., 2013). Therefore, the logic behind selecting outside directors is because of their expertise and abilities, which brings better performance to the firm. In the same line of this discussion (Doha \& McConnell, 2007) have found that firms with a bigger portion of independent directors are more progressed with their operations, rendering with the better stock prices in the stock market. Based on the agency theory prediction of the independent directors becoming as an instrument of providing safeguard for the shareholders, especially the minority (Barroso Casado et al., 2016; SetiaAtmaja, 2009), this suggests that firms that have a bigger portion of independent directors in their board have the potential to have a stronger governance enforcement. It has been established through studies that the bigger the portion of independent directors sitting on the board can be a sign of greater chances for dispensing dividends (Sharma, 2011). As a result, there will not be a free cash flow left within the manager's reach to invest it at the expense of the owners (Guest, 2008; Jensen, 1986) and subsequently the dividends lessen the agency costs (Easterbrook, 1984; Rozeff, 1982). Up on this discussion, the study 
hypothesis is:

\section{H2: The bigger number of independent directors sitting on the board the higher the chance to dispense dividends.}

\subsection{Independent Variable: Board Diversity}

It is referring to the female directors sitting on the board of directors. Past researches tried to connect gender diversity with agency theory. They proved that female directors impose a bigger influence on agency theory. Therefore, (Jurkus et al., 2011) supported their prediction that agency costs can be reduced if there is a bigger portion of female directors on the board. They found out the more diverse the board is might make a favorable impact on the firms, for example improving the board control (Mustafa et al., 2017). Status characteristics theory besides the agency theory, which emphasized the importance of existence of female directors sitting within the board, could clarify diversity in terms of gender (Larkin et al., 2013). According to it persons having low status could raise higher scales of capability similar to those with high status and will be understood as the same as theirs (Terjesen et al., 2009). According to (Hillman et al., 2002) in order for a female to be considered as a capable person, she has to show extra exhibition of capability higher that what is required from a male person. The research discovered as well the female directors employed within Fortune 1000 firms obtain more advanced degrees relative to the male directors. Experimental evidences back the idea that female directors have an indispensable part in firm regulations. According to researches female directors given to be more concentrated than their male associated directors plus in order to decide any decision they need thorough information (Stendardi et al., 2006). This is in accordance to (Ittonen et al., 2010) who found that female directors possess effectiveness and efficiency within each level of the board and committee which can result in reduction of the audit costs. Therefore, will apply their proficiencies and experiences to do practice their responsibilities persistently. Moreover, (Byoun et al., 2016) conducted a comparison of multi boards of directors in regard with the gender and found that the more gender diversty is present within the boards the higher the payment of dividends were present. Thus, this discovery is a sign that female directors within the board might utilize dividends to minimize the agency costs in organizations. Finally, (PuchetaMartínez \& Bel-Oms, 2016) stated that the bigger existence of female directors within board of directors will increase chances of paying dividends. Hence, the study hypothesis is:

\section{H3: Board diversity and decision to pay dividends are positively related}

\subsection{Control Variables ROA, LEVE}

In addition to the dependent and independent variables, we included two control variables each of Return on Asset (ROA) and Leverage (LEVE) to reduce the likelihood of reporting spurious results.

\subsection{Model specification}

In order to reach the study objectives, the relation between board characteristics (board size, independence, and diversity) and dividends have been examined through the following model, which measures the study hypothesis:

$$
\begin{gathered}
\text { DIVI }_{i t}=\beta_{0}+\beta_{1} B O A S_{i t i t}+\beta_{2} B O A I_{i t}+\beta_{3} B O A D_{i t}+\beta_{4} \\
\operatorname{ROA}_{i t}+\beta_{5} L E V E_{i t}+\varepsilon_{i t .}
\end{gathered}
$$

DIVI is a binary the dependent variable ' 1 ' a firm pays dividend, otherwise' 0 '.

\begin{tabular}{|c|c|c|}
\hline DIVI $_{\text {it }}$ & $=$ & Dividend \\
\hline BOAS & $=$ & Board size \\
\hline BOAI & $=$ & Board Independence \\
\hline BOAD & $=$ & Board diversity \\
\hline ROA & $=$ & Return on Assets \\
\hline LEVE & $=$ & Leverage \\
\hline
\end{tabular}

For each firm (i) and each year (t) scattered with constant differences. 
Table 1: Variable definitions

\begin{tabular}{|c|c|c|c|c|}
\hline Code & Variable name & \multicolumn{3}{|c|}{ Operationalization } \\
\hline DIVI & Dividends & \multicolumn{3}{|c|}{$\begin{array}{l}\text { DIVI is the dependent binary variable ' } 1 \text { ' is a firm } \\
\text { paying dividends, and ' } 0 \text { ' is otherwise. }\end{array}$} \\
\hline BOAS & Board size & \multicolumn{3}{|c|}{ The number of the board directors. } \\
\hline BOAI & Board independence & \multicolumn{3}{|c|}{$\begin{array}{l}\text { The portion of independent directors within the board to } \\
\text { total number of directors. }\end{array}$} \\
\hline BOAF & Board diversity & \multicolumn{3}{|c|}{$\begin{array}{l}\text { The female director occupy position on the board of } \\
\text { directors. }\end{array}$} \\
\hline ROA & Return on assets & \multicolumn{3}{|c|}{$\begin{array}{l}\text { It the rate of accounting earnings before the interest and } \\
\text { taxes to the book value of assets. }\end{array}$} \\
\hline LEVE & Total debt/total assets ratio & \multicolumn{3}{|c|}{$\begin{array}{l}\text { Total amount of a firms liabilities divided by } \\
\text { the total amount of the company's assets }\end{array}$} \\
\hline \multicolumn{5}{|c|}{ DESCRIPTIVE STATISTICS } \\
\hline \multirow{2}{*}{\multicolumn{5}{|c|}{ 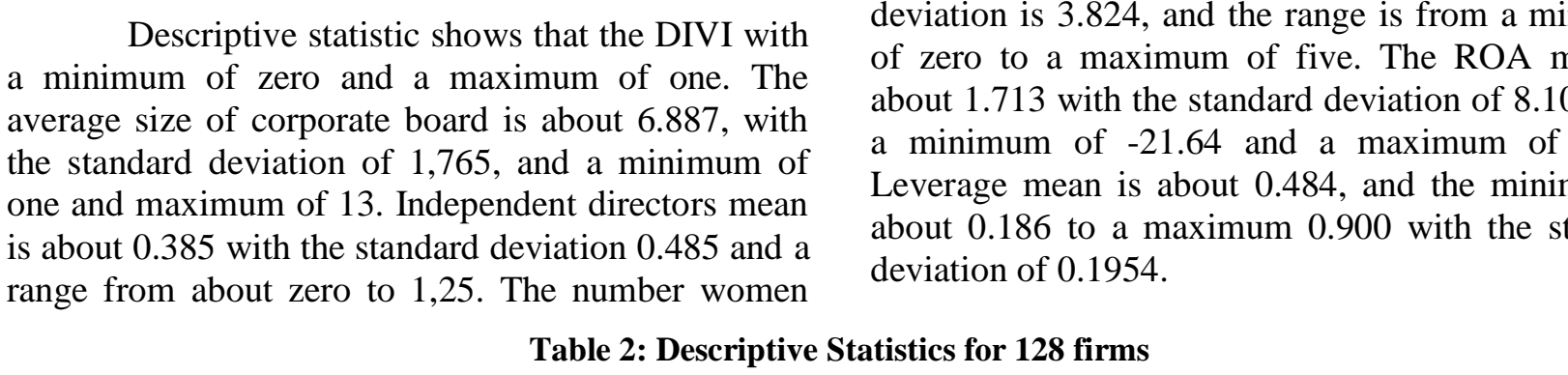 }} \\
\hline & & & & \\
\hline Variable & \multicolumn{2}{|c|}{ Mean } & Min & Max \\
\hline DIVI & \multicolumn{2}{|l|}{128} & 0 & 1 \\
\hline BOAS & \multicolumn{2}{|c|}{6.886792} & 1 & 13 \\
\hline BOAI & .3845559 & .4845919 & 0 & 1.25 \\
\hline BOAF & \multicolumn{2}{|c|}{2.8} & 0 & 5 \\
\hline ROA & 1.713284 & 8.102566 & -21.64 & 32.16 \\
\hline LEVE & 0.484 & 0.1954 & 0.186 & 0.900 \\
\hline
\end{tabular}

\section{CORRELATION}

The correlation coefficient values are less than 0.80 and for ROA is almost 0.80 . Thus, multicollinearity problems do not exist among the variables of interest except for ROA. 
Table 3 Correlation Matrix of the Studied Variables.

\begin{tabular}{llccccc}
\hline Variable & DIVI01 & BOAS & BOAI & BOAF & ROA & LEVE \\
\hline DIVI & 1.0000 & & & & \\
BOAS & 0.0358 & 1.0000 & & & \\
BOAI & $0.1754^{*}$ & -0.0221 & 1.0000 & & \\
BOAF & $0.2101 *$ & $0.4377 *$ & $0.8586^{*}$ & 1.0000 & \\
ROA & $0.7950^{*}$ & 0.0033 & $0.1797 *$ & $0.1832^{*}$ & 1.0000 & \\
LEVE & -0.0200 & 0.1666 & -0.0055 & -0.0788 & 0.0112 & 1.0000
\end{tabular}

It show's that there is a positive correlation between DIVI and all the variables except of LEVE which is a negative correlation.

\section{SONUÇ}

The independent variables explain about $24 \%$ of the differences in the dependent variable because the regression result shows $\mathrm{R}^{2}$ is $23.7 \%$ (Table 4). This indicates that BOAS, BOAI and BOAF derive about $23.7 \%$ of the variances in the dividends. The results show that firms with bigger board of directors make bigger chance of dispensing dividends $(\mathrm{p}<0.05)$. The finding aligns with Hypothesis 1, which presumes that the size of the board has a positive effect on the dividend decision. The result is in agreement with (Al-Najjar \& Kilincarslan, 2016; Litai et al., 2011; Uwalomwa et al., 2015) whom they discovered a positive relations between the size of the board and a decision of paying dividend. It indicates the firms that have a bigger board of directors might have more experienced personals and professionals who have wide views and knowledge that lead to a wise decision.

Table 4 Regression Model

\begin{tabular}{lcccc}
\hline Variables & Coef. & Std. Err. & $\mathrm{T}$ & $\mathrm{P}>|\mathrm{t}|$ \\
\hline BOAS & .099702 & .0489512 & 2.04 & $* * 0.044$ \\
BOAI & .5642679 & .3120768 & 1.81 & $* 0.073$ \\
BOAF & .0820616 & .0443327 & 1.85 & $* 0.066$ \\
ROA & .0256368 & .0049506 & 5.18 & $* * * 0.000$ \\
LEVE & -.0050 & .002 & -2.20 & $* * 0.030$ \\
R-squared & 0.237 & & & \\
Prob $>$ chi ${ }^{2}$ & 0.0000 & & & \\
\hline
\end{tabular}

Notes: $*=$ significant at $10 \%, * *=$ significant at $5 \%$ and $* * *=$ significant at $1 \%$.

In addition, shareholders interest will be more protective by these directors if cash is going to be distributed as dividends. (Belden et al., 2005) found that bigger boards of directors have probably greater controlling because the decisions that come from the chief executives will go through a diverse number of directors. The findings is aligned with the agency theory which states that the dividends are a way of protecting shareholders (La Porta et al., 2000; Rozeff,
1982).

Board composition BOAI referring to independent directors sitting among the board of directors, has a positive effect on paying dividends. The experimental proofing indicates a strong positive link in between the board composition BOAI and a decision of paying dividends. It has settled at the level of $p<0.1$ from table 4 . Therefore, the existence of 
bigger number of independent directors sitting on the board will guarantee payment of dividends to the shareholders and thus lessening the agency costs. The results are consistent with the previous proof that the bigger number of independent directors will raise the probability to dispense higher dividends (Adjaoud \& Ben-Amar, 2010; Litai et al., 2011; Sharma, 2011; Yarram \& Dollery, 2015). Therefore, our finding supports free role of the independent directors and the dividends that work in the firm's settings. Thus, this is in line with Hypothesis 2 that a decision of dispensing dividends has a positive association with having a bigger number of independent directors.

Finally, hypothesis 3 which refers to the effect of gender within the board of directors on the decision of dividend payment is supported as well. The research finding show a favorable and considerable link between the existence of female directors siting in the board and the probability of paying dividends. The argument support many studies' findings like (Byoun et al., 2016; PuchetaMartínez \& Bel-Oms, 2016), and others who proved to have female directors within the board will raise the likelihood to pay dividends resulting in more protection to the interests of shareholders. Therefore, the results back the agency theory of the dividends as a tool of mitigating the agency conflict between managers and shareholders of the firm (Jurkus et al., 2011).

Moreover, the results support the status characteristics theory. According to the theory the persons with low status will try to show higher levels of talent one the same of the high status of other members like the males who control the board would be realized theirs (Terjesen et al., 2009). In this case, the female directors on the board will try to show additional hard work to prove her ability of dealing with corporate board's various issues and to protect the owners of the firm at the level of the board and committees (Ittonen et al., 2010).

Both return on assets ROA and leverage are control variables used besides the main variables. The findings show that ROA has a positive effect of the dividends and leverage. This implicates that firms with high profits have higher probability for paying dividends and this is in accordance with the $(\mathrm{Hu} \&$
Kumar, 2004; Sharma, 2011) findings.

The study proves that leverage has a negative coefficient and marginal influence. Firms with higher leverages have a lower likelihood to pay dividends (and pay lower dividends) in the Jordan market. The finding is supported by the findings of (Al-Najjar \& Kilincarslan, 2016).

\section{CONCLUSIONS}

This paper examines the impact of board of directors' characteristics (board size, board independence and board gender) that impose on the corporate dividend policy. The evidence is from Amman Stock Exchange Market, it is a sample of all listed firms in the Manufacturing sector, which consist of 44 companies for three years from 20162018.

The panel corrected standard errors (PCSEs) regression is used to examine the objectives of the study and to the controls of the problem's heteroscedasticity and Autocorrelation in the sample firms used.

The results show a positive correlation between the independent variables of (Board Size, Board independence and board diversity) and the dependent variable of Dividends. This indicates that the bigger the size of the board of directors and having more independent directors sitting within the board and the more female directors are in the board are all factors that will encourage the Jordanian companies to pay dividends to their shareholders.

The research recommend that Jordanian manufacturing companies comply with the Jordanian code of corporate governance and diversify their corporate boards of directors by appointing more outside directors and more female directors within their boards.

The research recommends that more studies be conducted, including more variables and additional attributes of the board of directors' members, example: ownership, level of education, and other measurements to measure the dividends. 


\section{REFERENCES}

Abbadi, S. S., Hijazi, Q. F., \& Al-Rahahleh, A. S. (2016). Corporate governance quality and earnings management: Evidence from Jordan. Australasian Accounting, Business and Finance Journal, 10(2), 54-75.

Abor, J., \& Fiador, V. (2013). Does corporate governance explain dividend policy in Sub-Saharan Africa? International Journal of Law and Management.

Adjaoud, F., \& Ben-Amar, W. (2010). Corporate governance and dividend policy: shareholders' protection or expropriation? Journal of Business Finance \& Accounting, 37(5-6), 648667.

Al-Najjar, B., \& Kilincarslan, E. (2016). The effect of ownership structure on dividend policy: evidence from Turkey. Corporate Governance: The International Journal of Business in Society.

Barroso Casado, R., Burkert, M., Dávila, A., \& Oyon, D. (2016). Shareholder protection: The role of multiple large shareholders. Corporate Governance: An International Review, 24(2), 105-129.

Belden, S., Fister, T., \& Knapp, B. O. B. (2005). Dividends and directors: do outsiders reduce agency costs? Business and Society Review, 110(2), 171-180.

Benjamin, S. J., \& Zain, M. M. (2015). Corporate governance and dividends payout: are they substitutes or complementary? Journal of Asia Business Studies.

Bokpin, G. A. (2011). Ownership structure, corporate governance and dividend performance on the Ghana Stock Exchange. Journal of Applied Accounting Research.

Boone, A. L., Field, L. C., Karpoff, J. M., \& Raheja, C. G. (2007). The determinants of corporate board size and composition: An empirical analysis. Journal of Financial Economics, 85(1), 66-101.

Byoun, S., Chang, K., \& Kim, Y. S. (2016). Does corporate board diversity affect corporate payout policy? Asia-Pacific Journal of Financial Studies, 45(1), 48-101.

Certo, S. T. (2003). Influencing initial public offering investors with prestige: Signaling with board structures. Academy of Management Review, 28(3), 432-446.

Dalton, D. R., Daily, C. M., Johnson, J. L., \& Ellstrand, A. E. (1999). Number of directors and financial performance: A meta-analysis. Academy of Management Journal, 42(6), 674-686.

De Villiers, C., Naiker, V., \& Van Staden, C. J. (2011). The effect of board characteristics on firm environmental performance. Journal of Management, 37(6), 1636-1663.

Easterbrook, F. H. (1984). Two agency-cost explanations of dividends. The American Economic Review, 74(4), 650 659 .
Fama, E. F., \& French, K. R. (2001). Disappearing dividends: changing firm characteristics or lower propensity to pay? Journal of Financial Economics, 60(1), 3-43.

Fama, E. F., \& Jensen, M. C. (1983). Separation of ownership and control. Journal of Law and Economics, 301-325.

Fatemi, A., \& Bildik, R. (2012). Yes, dividends are disappearing: Worldwide evidence. Journal of Banking \& Finance, $36(3), 662-677$.

Fernández, C., \& Arrondo, R. (2005). Alternative internal controls as substitutes of the board of directors. Corporate Governance: An International Review, 13(6), 856-866.

Guest, P. M. (2008). The determinants of board size and composition: Evidence from the UK. Journal of Corporate Finance, 14(1), 51-72.

Hillman, A. J., Cannella, A. A., \& Harris, I. C. (2002). Women and racial minorities in the boardroom: how do directors differ? Journal of Management, 28(6), 747-763.

Hu, A., \& Kumar, P. (2004). Managerial entrenchment and payout policy. Journal of Financial and Quantitative Analysis, 39(4), 759-790.

Ittonen, K., Miettinen, J., \& Vähämaa, S. (2010). Does female representation on audit committees affect audit fees? Quarterly Journal of Finance and Accounting, 113-139.

Jaara, B., Alashhab, H., \& Jaara, O. O. (2018). The determinants of dividend policy for non-financial companies in Jordan. International Journal of Economics and Financial Issues, 8(2), 198.

Jensen, M. C. (1986). Agency costs of free cash flow, corporate finance, and takeovers. The American Economic Review, $76(2), 323-329$.

Jensen, M. C. (1993). The modern industrial revolution, exit, and the failure of internal control systems. The Journal of Finance, 48(3), 831-880.

Jensen, M. C., \& Meckling, W. H. (1979). Theory of the firm: Managerial behavior, agency costs, and ownership structure. In Journal of financial economics (Vol. 3, Issue 4). Springer.

Jiraporn, P., Kim, J., \& Kim, Y. S. (2011). Dividend payouts and corporate governance quality: An empirical investigation. Financial Review, 46(2), 251-279.

Jurkus, A. F., Park, J. C., \& Woodard, L. S. (2011). Women in top management and agency costs. Journal of Business Research, 64(2), 180-186.

Kim, I., \& Kim, T. (2013). Changing Dividend Policy in Korea: Explanations Based on Catering, Risk, and the Firm's Lifecycle. Asia-Pacific Journal of Financial Studies, 42(6), 880-912. 
La Porta, R., Lopez-de-Silanes, F., Shleifer, A., \& Vishny, R. W. (2000). Agency problems and dividend policies around the world. The Journal of Finance, 55(1), 1-33.

Larkin, M. B., Bernardi, R. A., \& Bosco, S. M. (2013). Does female representation on boards of directors associate with increased transparency and ethical behavior? Accounting and the Public Interest, 13(1), 132-150.

Latif, R. A., Kamardin, H., Mohd, K. N. T., \& Adam, N. C. (2013). Multiple directorships, board characteristics and firm performance in Malaysia. Management, 3(2), 105111.

Linck, J. S., Netter, J. M., \& Yang, T. (2008). The determinants of board structure. Journal of Financial Economics, 87(2), 308-328.

Litai, C., Chuan, L. I. N., \& Kim, Y. (2011). Financial characteristics, corporate governance and the propensity to pay cash dividends of Chinese listed companies. International Business and Management, 3(1), 176-188.

Mustafa, A., Che-Ahmad, A., Chandren, \& Sitraselvi. (2017). Board diversity and audit quality: Evidence from Turkey. Journal of Advanced Research in Business and Management Studies, 6(1), 50-60.

Okafor, C. A., \& Chijoke-Mgbame, A. M. (2011). Dividend policy and share price volatility in Nigeria. Jorind, 9(1), $202-210$.

Pfeffer, J., \& Salancik, G. R. (2003). The external control of organizations: A resource dependence perspective. Stanford University Press.

Pucheta-Martínez, M. C., \& Bel-Oms, I. (2016). The board of directors and dividend policy: The effect of gender diversity. Industrial and Corporate Change, 25(3), 523547.

Rozeff, M. S. (1982). Growth, beta and agency costs as determinants of dividend payout ratios. Journal of Financial Research, 5(3), 249-259.

Setia-Atmaja, L. Y. (2009). Governance mechanisms and firm value: The impact of ownership concentration and dividends. Corporate Governance: An International Review, 17(6), 694-709.

Sharma, V. (2011). Independent directors and the propensity to pay dividends. Journal of Corporate Finance, 17(4), 10011015.

Short, H., Zhang, H., \& Keasey, K. (2002). The link between dividend policy and institutional ownership. Journal of Corporate Finance, 8(2), 105-122.

Stendardi, E. J., Graham, J. F., \& O'Reilly, M. (2006). The impact of gender on the personal financial planning process. Humanomics.
Terjesen, S., Sealy, R., \& Singh, V. (2009). Women directors on corporate boards: A review and research agenda. Corporate Governance: An International Review, 17(3), 320-337.

Uwalomwa, U., Olamide, O., \& Francis, I. (2015). The effects of corporate governance mechanisms on firms dividend payout policy in Nigeria. Journal of Accounting and Auditing, 2015, 1.

Yarram, S. R., \& Dollery, B. (2015). Corporate governance and financial policies. Managerial Finance.

Yermack, D. (1996). Higher market valuation of companies with a small board of directors. Journal of Financial Economics, 40(2), 185-211. 